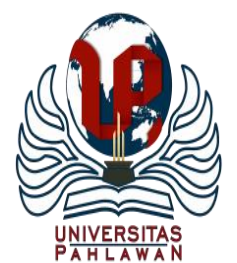

Edukatif : Jurnal Ilmu Pendidikan Volume 3 Nomor 1 Tahun 2021 Halm 220 - 226 EDUKATIF: JURNAL ILMU PENDIDIKAN

Research \& Learning in Education

https:/ledukatif.org/index.php/edukatif/index

\title{
Kondisi Psikologis Mahasisawa PGSD Universitas Muhammadiyah Buton (UMB) dalam Pelaksanaan Pembelajaran Daring di Masa Pandemi
}

\author{
Syamsurijal $^{1 凶}$, Sarwan $^{2}$ \\ Universitas Muhammadiyah Buton, Baubau, Indonesia ${ }^{1,2}$ \\ E-mail : zmbrhijal@ gmail.com ${ }^{1}$, sarwanthudal98@ gmail.com ${ }^{2}$
}

\begin{abstract}
Abstrak
Pelaksanaan pembelajaran daring di masa pandemi memunculkan berbagai masalah bagi peserta didik termasuk keluhan kondisi psikologis, maka dari itu perlu dilakukan suatu penelitian untuk mendeteksi bagaimana kondisi psikologi mahasiswa selama penerapan pembelajaran daring. Jenis penelitian yang digunakan adalah metode penelitian kuantitatif dengan menggunakan metode Survey. Variabel penelitian yaitu keluhan psikologis dalam pelaksanaan pembelajaran daring dan mahasiswa PGSD Universitas Muhammadiyah Buton. Subjek penelitian ialah mahasiswa PGSD Universitas Muhammadiyah Buton (UM. Buton) yang dipilih dengan menggunakan teknik simple Random Sampling sehingga diperoleh 80 sampel penelitian. Hasil penelitian menunjukkan bahwa secara deskriptif bahwa mahasiswa mengalami keluhan psikologis dalam mengikuti pembelajaran daring dimasa pandemic, hal tersebut diukur menggunakan indikator psikologis. Adapun keluhan psikologis yang dialami oleh mahasiwa yakni; 77,5\% mahasiswa bosan dan tidak bosan $22,5 \%$, cemas $45 \%$ dan tidak cemas adalah $55 \%$, stress $57,5 \%$ dan tidak stress $42,5 \%$, resah $57,5 \%$ dan tidak resah ada $42,5 \%$, pusing $73,8 \%$ dan tidak pusing ada $26,2 \%$ dan mahasiswa yang berharap agar pembelajaran daring segera berakhir ada $95 \%$ dan yang merasa tidak resah ada,5\%. Kesimpulannya adalah terdapat keluhan psikologi yang dialami mahasiswa PGSD Universitas Muhammadiya Buton (UMB) dalam mengikuti pembelajaran daring di masa pendemi. Dengan hasil penelitian ini diharapkan pendidik lebih selektif dalam memilih metode dan sarana pembelajaran daring.

Kata Kunci : Kondisi Psikologis, Pembelajaran Daring
\end{abstract}

\begin{abstract}
The implementation of online learning during a pandemic raises various problems for students including complaints of psychological conditions, therefore it is necessary to conduct a study to detect how the psychological condition of students during the application of online learning. This type of research is a quantitative research method using the survey method. The research variables were psychological complaints in the implementation of online learning and PGSD students at the Muhammadiyah University of Buton. The research subjects were PGSD students of Muhammadiyah Buton University (UM. Buton) who were selected using simple random sampling technique so that 80 research samples were obtained. The results showed that descriptively that students experienced psychological complaints in participating in online learning during the pandemic, this was measured using psychological indicators. As for the psychological complaints experienced by students, namely; $77.5 \%$ students are bored and not bored $22.5 \%$, anxious $45 \%$ and not anxious is 55\%, stressed $57.5 \%$ and not stressed $42.5 \%$, restless $57.5 \%$ and not anxious there are $42.5 \%$, dizziness $73.8 \%$ and no headache $26.2 \%$ and students who hope that online learning will end soon is $95 \%$ and there are $5 \%$ who feel uneasy. The conclusion is that there are psychological complaints experienced by PGSD students of Muhammadiya Buton University $(U M B)$ in participating in online learning during the pandemic. With the results of this study, it is hoped that educators will be more selective in choosing methods and means of online learning

Keywords: Psychological Conditions, Online Learning
\end{abstract}

Copyright (c) 2021 Syamsurijal, Sarwan

$\triangle$ Corresponding author

Email:zmbrhijal@gmail.com

DOI : https://doi.org/10.31004/edukatif.v3i1.290

ISSN 2656-8063 (Media Cetak)

ISSN 2656-8071 (Media Online)

Edukatif : Jurnal Ilmu Pendidikan Vol 3 No 1 Tahun 2021 p-ISSN 2656-8063 e-ISSN 2656-8071 
221 Kondisi Psikologis Mahasisawa PGSD Universitas Muhammadiyah Buton (UMB) dalam Pelaksanaan Pembelajaran Daring di Masa Pandemi - Syamsurijal, Sarwan

DOI: https://doi.org/10.31004/edukatif.v3i1.290

\section{PENDAHULUAN}

(Marzuki, 2012) Pendidikan nasional bertujuan mencerdaskan kehidupan bangsa dan mengembangkan manusia indonesia yang seutuhnya, yaitu manusia yang beriman dan bertaqwa kepada tuhan yang maha Esa dan berbudi pekerti luhur, memiliki pengetahuan dan keterampilan, kesehatan jasmani dan rohani, kepribadian yang mantap dan mandiri serta rasa tanggung jawab kemasyarakatan dan kebangsaan (Pasal 4 UU No. 23 tahun 2003).

Pendidikan yang berkualitas adalah syarat mutlak demi majunya suatu bangsa, pendidikan yang mampu menghadirkan output yang berkualitas akan memberikan efek positif dalam menunjang kemajuan suatu bangsa. Layanan pendidikan yang maksimal kepada peserta didik dituntut agar pembelajaran tetap bisa berlangsung dalam berbagai kondisi dan situasi.

Pendidikan di Indonesia dari masa ke masa selalu lekat dengan berbagai tantangan yang mesti dicarikan solusi terbaik. Jika selama ini pembelajaran tatap muka adalah hal yang lumrah dilakukan di lembaga-lembaga pendidikan, maka hal tersebut sontak berubah menjadi antiklimaks setelah munculnya virus Covid-19 yang menjadi titik kulminasi dari pembelajaran tatap muka.

Kemunculan Virus Covid-19 menjadi guncangan bagi dunia pendidikan, Virus Covid-19 yang bisa menular dengan mudah dan bisa membawa konsekuensi kematian bagi penderitanya, tak ayal membuat stackholder dunia pendidikan harus memutar otak, agar pembelajaran tetap bisa dilaksanakan.

Adalah hal yang riskan jika kegiatan pembelajaran tetap dipaksakan dalam konsep pembelajaran tatap muka di tengah pandemi Covid-19 yang masih mengintai. Sehingga sebagai opsi terbaik agar pembelajaran tetap bisa berjalan dan tujuan pembelajaran tetap bisa diupayakan agar bisa maksimal tercapai adalah dengan mengalihkan dari pembelajaran tatap muka ke pembelajaran berbasis daring. Dalam Uswatun Hasanah dkk (2020) juga dipaparkan tentang Surat Edaran Mendikbud Nomor 36962/MPK.A/HK/2020 menyatakan agar seluruh kegiatan belajar mengajar baik di sekolah maupun kampus perguruan tinggi menggunakan metoda daring atau online sebagai upaya pencegahan terhadap perkembangan dan penyebaran Coronavirus disease (Covid-19). Sejalan dengan hal tersebut "Sejak tanggal 11 Maret 2020 WHO menetapkan corona virus disease 2019 (covid-19) sebagai pandemi berskala global, banyak negara di dunia yang menetapkan kebijakan social distancing dan bahkan physical distancing untuk menghambat penyebaran Covid-19. (R. Kartika, 2020) Pembelajaran daring setidaknya bisa menjadi antitesa dalam menekan menyebaranya Virus Covid-19, juga bisa meminimalisir resiko peserta didik dari terpapar virus Covid-19. Dengan sistem pembelajaran daring maka pembelajaran dilaksanaka secara daring atau online, jadi peserta didik tidak mesti datang ke sekolah untuk mengikuti pembelajaran, cukup dengan menggunakan Smartphone atau computer yang terkoneksi dengan peserta didik bisa ikut dalam kegiatan pembelajaran.

Namun seperti biasa, tidak semua ekspektasi akan berjalan seirama dengan kondisi yang ada. Penerapan pembelajaran daring bukan tanpa kendala, banyak hal yang menjadi catatan dalam penerapan pembelajaran daring di masa pandemi. Setidaknya ada beberapa kendala yang dihadapi oleh guru dan siswa dalam pelaksanaan pembelajaran daring di masa pandemi.

Seperti yang kita ketahui beberapa poin penting dari suksesnya pembelajaran daring adalah ketersedian koneksi internet yang bisa mendukung kelas virtual atau maya tetap terlaksana, sarana untuk pembelajaran daring seperti smartphone dan komputer yang ternyata tidak semua peserta didik memilikinya dan pastinya agar bisa terkoneksi dengan internet peserta didik harus memiliki kuota internet, sedangakan harga kuota internet juga agak mahal sehingga menjadi masalah klasik dalam pendidikan di Indonesia. 
Terlepas dari faktor-faktor eksternal yang menjadi problematika dalam pelaksanaan pembelajaran daring, yang tidak kalah menarik untuk dibahas adalah ternyata penerapan pelakasanaan pembelajaran berbasis daring juga berpengaruh terhadap kondisi psikologis peserta didik.

Lantas yang menjadi pertanyaan adalah apakah penerapan pembelajaran daring di masa pandemi berimplikasi positif terhadap kondisi psikologi peserta didik atau justru penerapan pembelajaran daring di masa pandemic justru berimplikasi negatif terhadap kondisi psikologis peserta didik khususnya mahasiswa PGSD Universitas Muhammadiyah Buton (UM. Buton). Untuk itu peneliti berinisiatif melakukan penelitian dengan judul: Kondisi Psikologis Mahasiswa PGSD Universitas Muhammadiyah Buton (UMB) dalam Pelaksanaan Pembelajaran Daring di Masa Pandemi.

Definisi kondisi psikologis dalam konseling Secara umum kondisi psikologis merupakan keadaan, situasi yang bersifat kejiwaan. (Hartono \& Boy S, 2012). Sedangkan jika ditinjau dari aspek pendidikan maka dipahami bahwa psikologi pendidikan merupakan ilmu yang membahas segi-segi psikologi dalam lapangan pendidikan dimana psikologi pendidikan adalah studi ilmiah mengenai tingkah laku individu dalam situasi pendidikan. (Syah, 2010). Pemahaman Psikologi oleh Pendidik terhadap peserta didik dalam proses pembelajaran aktif hendaknya menjadi fokus yang tidak boleh diabaikan mengingat keaktifan belajar peserta didik ada pengaruhnya dengan kemauan, minat dan motivasi sehingga merupakan hal yang menjadikan penentu keberhasilan seorang pendidik ketika mengajar. Pendidik tidak hanya mengajar namun dalam prosesnya melibatkan para peserta didiknya lebih berperan aktif yaitu mengoptimalkan keseluruhan potensi yang dimiliki peserta didik baik fisik maupun psikis sehingga dapat berkembang secara optimal. (Rohman, 2019). Dalam penerapan pembelajaran daring tidak sedikit memicu munculnya keluhan psikologis pada mahasiswa. Keluhan Psikologis dapat berupa perasaan khawatir, perasaan tidak enak, tidak pasti atau merasa sangat takut sebagai akibat dari suatu ancaman atau perasaan yang mengancam dimana sumber nyata dari kecemasan tersebut tidak diketahui dengan pasti. Kecemasan mempengaruhi hasil belajar mahasiswa, karena kecemasan cenderung menghasilkan kebingungan dan distorsi persepsi. Distorsi tersebut dapat mengganggu belajar dengan menurunkan kemampuan memusatkan perhatian, menurunkan daya ingat, mengganggu kemampuan menghubungkan satu hal dengan yang lain. (Suntiawati \& Westa, 2015).

Oktawirawan dalam (D. Kartika, 2020) menemukan bahwa menjalani pembelajaran jarak jauh pada kondisi Covid-19 saat ini, siswa mengalami tingkat kecemasan cukup tinggi karena beberapa faktor yaitu karena kesulitan memahami materi, sulit mengerjakan tugas-tugas, keterbatasan kondisi jaringan internet dan bergam kendala teknis lainnya. Penelitian ini membuktikan bahwa secara psikologis, pembelajaran jarak jauh menyebabkan kekhawatiran serta kecemasan yang dapat mengganggu kesehatan mental siswa. Orang tua pun mengakui bahwa banyak anak mereka yang mengalami stress akibat tugas yang banyak selama pembelajaran daring seperti ini. Selian itu berdasarkan penelitian yang dilaksanakan. (Pratama, 2013) Tujuan dari penelitian ini ialah untuk mengetahui gambaran tingkat kecemasan, stres, serta depresi mahasiswa PGSD Penjas UPI Kampus Sumedang terhadap pengerjaan skripsi dalam situasi pandemi covid-19. . Metode penelitian deskriptif kuantitatif dengan desain survey. Instrumen yang digunakan kuisioner DASS-42. Dari 53 mahasiswa yang dijadikan sampel diperoleh hasil kecemasan; 28\% sangat parah, 26,40\% sedang, 18,90\% parah, 17,00\% ringan, 9,40\% normal. Stres; 39,60\% normal, 20,80\% ringan, 18,90\% parah, 17,00\% sedang, 3,80\% sangat parah. Depresi 37,70\% normal, 22,60\% ringan 18,90\% seang, 15,10\% parah, 5,70\% sangat parah. Penelitian lain menjelaskan bahwasanya bahwa mahasiswa yang memiliki tingkat kecemasan pada masa pandemic covid-19 dominan memiliki tipe kepribadian introvert. Keadaan ini menunjukkan tipe kepribadian introvert berisiko lebih besar mengalami kecemasan dibandingkan dengan mahasiswa dengan tipe kepribadian ekstrovert.

Pembelajaran daring merupakan sistem pembelajaran yang dilakukan dengan tidak bertatap muka langsung, tetapi menggunakan platform yang dapat membantu proses belajar mengajar yang dilakukan 
meskipun jarak jauh. Tujuan dari adanya pembelajaran daring ialah memberikan layanan pembelajaran bermutu dalam jaringan yang bersifat masif dan terbuka untuk menjangkau peminat ruang belajar agar lebih banyak dan lebih luas (Rozaq \& Sofyana, 2019). Sejalan dengan itu (Sofyana \& Rozaq, 2019) Memaparkan bahwasanya Pembelajaran Daring bertujuan memberikan layanan pembelajaran bermutu dalam jaringan (daring) yang bersifat masif dan terbuka untuk menjangkau peminat yang lebih banyak dan lebih luas. Pembelajaran daring merupakan inovasi pendidikan untuk menjawab tantangan akan ketersediaan sumber belajar yang variatif. Keberhasilan dari suatu model ataupun media pembelajaran tergantung dari karakteristik peserta didiknya (Dewi, 2020). Menurut Windhiyana dalam (Rosali, 2020), kelebihan dalam melakukan pembelajaran online, salah satunya adalah meningkatkan kadar interaksi antara mahasiswa dengan dosen/guru, pembelajaran dapat dilakukan dimana dan kapan saja (time and place flexibility), Menjangkau peserta didik (mahasiswa) dalam cakupan yang luas (potential to reach a global audience), dan mempermudah penyempurnaan dan penyimpanan materi pembelajaran (easy updating of content as well as archivable capabilities).

Penelitian yang dilakukan oleh (Fuadi \& Irdalisa, 2020) dimana Penelitian ini bertujuan untuk mengetahui berbagai jenis aplikasi yang digunakan pada proses pembelajaran daring di Perguruan Tinggi selama masa darurat pencegahan penyebaran COVID-19. Penelitian ini menggunakan studi literatur terhadap beberapa artikel yang membahas terkait pembelajaran daring di perguruan tinggi dengan mengunjungi berbagai halaman atau artikel dari World Wide Web. Pemaparan hasil dilakukan secara naratif. Adapun hasil dari penelitian menunujukkan ada 9 jenis aplikasi yang sering digunakan pada proses pembelajaran daring. Adapun 9 jenis aplikasi yang sering digunakan tersebut antara lain; (1) zoom, (2) google classroom, (3) Whatapp group, (4) google meet, (5) skype, (6) Webex, (7) email, (8) Edmodo dan (9) camstudio.

\section{METODE PENELITIAN}

Jenis penelitian penelitian digunakan adalah kuantitatif dengan metode penelitian Survei. Penelitian survei atau lengkapnya self administered adalah metode pengumpulan data primer. Metode survei digunakan sebagai teknik penelitian melalui pengamatan langsung terhadap suatu gejala atau pengumpulan informasi melalui pedoman wawancara, kuisioner, kuisioner terkirim atau survey melalui telepon/smartphone (Mubarok et al., 2020). Peneliti dalam penelitian ini akan menelusuri hipotesis yang dirumuskan sebelumnya yakni: Kondisi Psikologis Mahasiswa PGSD Universitas Muhammadiyah Buton (UMB) dalam Pelaksanaan Pembelajaran Daring di Masa Pandemi.

Variabel yang terdapat dalam penelitian ini terdiri atas 2 jenis variabel yaitu terdiri dari satu variabel bebas dan satu variabel terikat. variabel bebas yaitu Kondisi Psikologis Mahasiswa PGSD UM.Buton sedangkan variabel terikat adalah penerapan pembelajaran daringi di masa pandemi.

Populasi dalam penelitian ini adalah semua mahasiwa PGSD UM.Buton. Metode pengambilan sampel dalam penelitian ini adalah menggunakan simple random sampling. Dalam menentukan responden dengan menggunakan teknik simple random sampling Terlebih dahulu menentukan secara keseluruhan apa yang menjadi unit utama sampelnya (primary sampling units) dalam penelitian ini unit utamanya yaitu dikhususkan mahasiswa PGSD UM.Buton. Pada tahap ini digunakan penarikan sampel dengan menggunkan simple random sampling, dimana peneliti memilih sampel secara acak dan memberikan peluang kepada setiap unit populasi untuk terpilih sebagai sampel penelitian.

Instrumen yang digunakan dalam penelitian ini berupa Angket yang berisikan pertanyaan-pertanyaan untuk mengetahui kondisi psikologis mahasiswa dalam penerapan pembelajaran daring selama masa pandemic covid-19 di prodi PGSD UM.Buton, data rujukan untuk menjawab hipotesis penelitian. Teknik analisis data yang digunakan adalah analisis statistik deskriptif yang terdiri diagram distribusi frekuensi. 
224 Kondisi Psikologis Mahasisawa PGSD Universitas Muhammadiyah Buton (UMB) dalam Pelaksanaan Pembelajaran Daring di Masa Pandemi - Syamsurijal, Sarwan

DOI: https://doi.org/10.31004/edukatif.v3i1.290

\section{HASIL DAN PEMBAHASAN PENELITIAN}

Tabel. 1 Kondisi Psikologis 80 Mahasiswa PGSD Universitas Muhammadiyah Buton (UMB) dalam pelaksanaan pembelajaran daring di masa pandemi.

\begin{tabular}{|c|l|c|c|c|}
\hline NO & $\begin{array}{c}\text { Kondisi Psikologis } \\
\text { Mahasiswa PGSD } \\
\text { UM.Buton }\end{array}$ & IYA (\%) & Tidak (\%) & Persentasi (\%) \\
\hline 1 & Bosan & 77,5 & 22,5 & $100 \%$ \\
\hline 2 & Cemas & 45 & 55 & $100 \%$ \\
\hline 3 & Stress & 57,5 & 52,5 & $100 \%$ \\
\hline 4 & Pusing & 73,8 & 26,2 & $100 \%$ \\
\hline 5 & $\begin{array}{l}\text { Akhiri Pembelajaran } \\
\text { Daring }\end{array}$ & 95 & 5 & \\
\hline
\end{tabular}

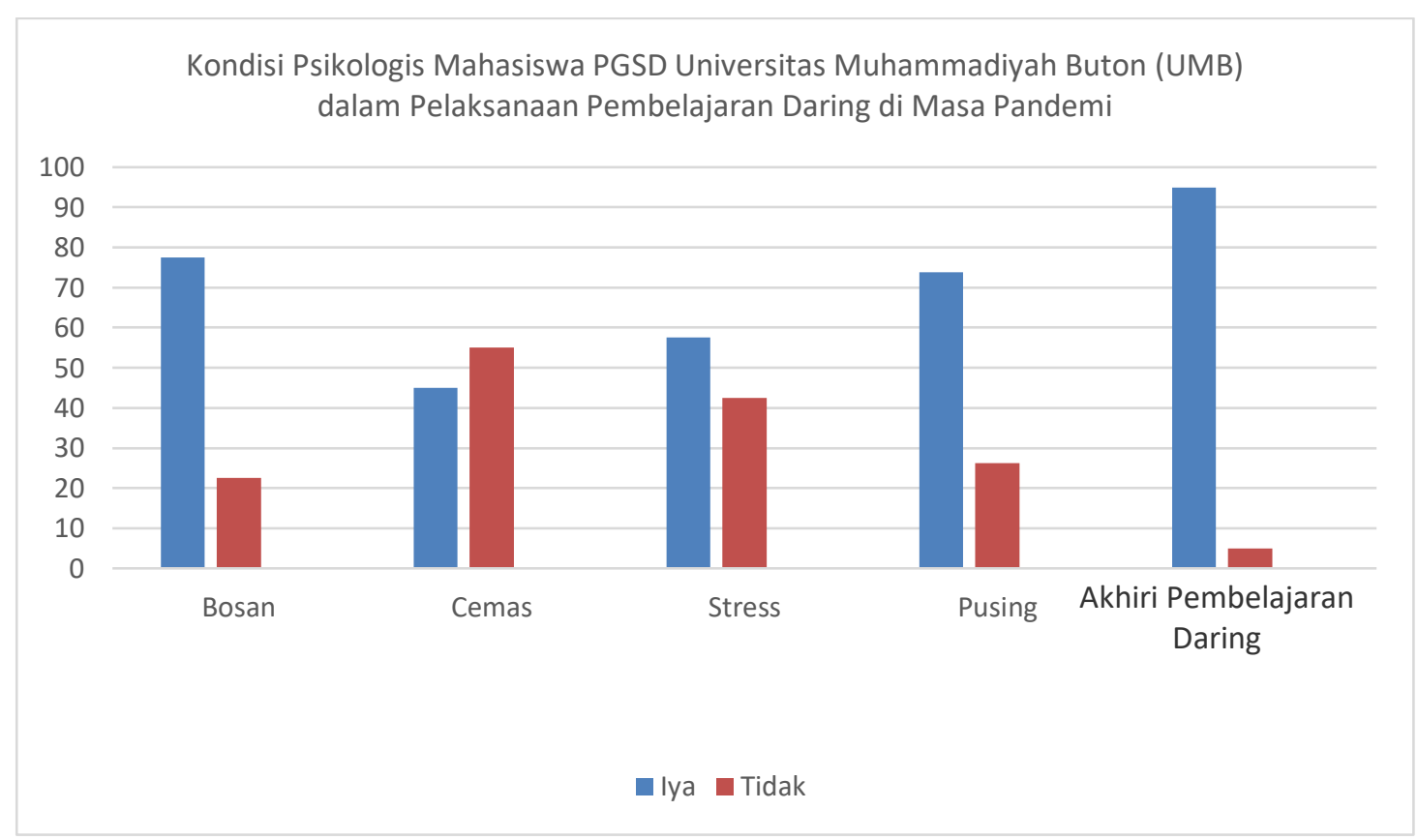

Gambar 1. Diagram Kondisi Psikologis Mahasiswa PGSD Universitas Muhammadiyah Buton (UMB) dalam Pelaksanaan Pembelajaran Daring di Masa Pandemi

Berdasarkan penelitian yang telah dilakukan menunjukan bahwa adapun keluhan psikologis yang dialami oleh 80 mahasiwa PGSD UM.Buton dalam penerapan pembelajaran daring dimasa pandemic yakni; mahasiswa yang merasa bosan dalam mengikuti pembelajaran daring di masa pandemi $77,5 \%$ dan yang merasa tidak bosan $22,5 \%$, mahasiswa yang merasa cemas $45 \%$ dan yang merasa tidak cemas adalah $55 \%$, mahasiswa yang merasa stress dalam mengikuti pembelajaran daring di masa pandemic ada 57,5\% dan yang merasa tidak stress ada $42,5 \%$, mahasiswa yang merasa resah dalam mengikuti pembelajaran daring di masa pandemi ada $57,5 \%$ dan yang merasa tidak resah ada $42,5 \%$, mahasiswa yang merasa pusing dalam mengikuti pembelajaran daring di masa pandemi ada $73,8 \%$ dan yang merasa tidak resah ada $26,2 \%$ dan mahasiswa yang berharap agar pembelajaran daring segera berakhir ada 95\% dan yang merasa tidak resah ada,5\%. Jadi kesimpulannya adalah terdapat keluhan psikologi yang dialami mahasiswa PGSD Universitas Muhammadiya 
Buton (UMB) dalam mengikuti pembelajaran daring di masa pendemi dan mahasiswa dan berharap agar penerapan pembelajaran daring di masa pandemi segera berakhir.

Sejalan dengan itu Sebuah hasil riset garapan peneliti lintas-kampus di AS yang dirilis dalam Jurnal PLOS One pada 7 Januari 2021 lalu menggambarkan hal tersebut. Laporan berjudul "Psychological Impacts from COVID-19 Among University Students: Risk Factors Across Seven States in the United States" itu menyimpulkan, kualitas kesehatan mental sebagian besar mahasiswa di Amerika Serikat anjlok selama pandemi. Psikolog dan akademikus Clemson University di South Carolina, Matthew Browning menulis bahwa penelitian timnya tersebut dilandasi fakta, bahwa sebelum pandemi sekalipun kesehatan mental mahasiswa AS sudah tidak baik-baik saja. Banyak mahasiswa AS menghadapi masalah depresi, kecemasan, dan gangguan kesehatan mental lainnya pada tingkat yang lebih tinggi daripada populasi umum, pada tahuntahun sebelum Covid-19 membuat dunia tidak lagi sama. Situasi ini, menurut Browning dan timnya, terjadi karena para mahasiswa harus bergulat dengan lingkungan sosial baru, menghadapi tuntutan untuk meniti karier, hingga problem keuangan. Maka itu, Browning dan timnya melakukan survei yang melibatkan lebih dari 2.500 mahasiswa dari 7 universitas negeri di AS pada musim semi 2020, saat penularan virus corona melonjak. Kesimpulan survei itu adalah 85 persen mahasiswa mengalami tekanan emosional tingkat tinggi hingga sedang. Sebanyak 45 persen mahasiswa di antaranya mengalami tekanan level tinggi. Hasil riset tersebut semakin mempertegas bahwasanya pembelajaran daring dimasa pandemi sangat mempengaruhi kondisi psikologis peserta didik.

Untuk meminimlaisir keluhan psikologis yang dialami mahasiswa selama penerapan pembelajaran daring dimasa pandemi, (Deliviana et al., n.d.) Untuk mengatasinya, mahasiswa perlu mengelola kesehatan mental pribadi dengan dukungan internal maupun eksternal, seperti meningkatkan sisi spiritualitas, melakukan aktivitas fisik yang menyehatkan, membentuk kebiasaan berpikir dan merasa secara positif,maka diharapkan pendidik menerapkan model dan metode pembelaran yang variatif, serta lebih memperbanyak melakukan pendekatan kepada mahasiswa guna mencari formulasi pembelajaran yang tepat digunakan selama pembelajaran daring. Selain itu pemilihan media pembelejaran online misalnya melalui; WhatssApp, Zoom, Google Classroom, Youtube, harus mampu mengakomodir kebutuhan belajar mahasiswa. Dan yang paling penting adalah pemberian tugas kuliah yang proporsional sehingga meminimalisir keluhan psikologis mahasiswa. Namun Penelitian ini juga memiliki beberapa keterbatasan misalnya keterbatasan biaya dan waktu, namun semoga penelitian ini bisa menjadi refrensi bagi peneliti lain atau bisa menjadi acuan dalam melakukan penelitian yang meneliti tentang kondisi psikologi mahasiswa.

\section{KESIMPULAN}

Berdasarkan Survei yang dilakukan oleh peneliti menunjukan bahwa penerapana pembelajaran berbasis daring di masa pandemi memicu munculnya kondisi psikologis mahasiswa PGSD UM.Buton seperti; stress, resah cemas, bosan dan pusing. Adapun tindak lanjut dari hasil temuan dari penelitian ini adalah peneliti berharap hasil penelitian ini bisa menjadi rujukan dan bahan pertimbangan bagi rekan-rekan pendidik dalam memilih metode dan sarana dalam pelaksanaan pembelajaran daring di masa pandemic guna meminimalisir perasaan stress, resah cemas, bosan dan pusing yang dialami peserta didik.

\section{UCAPAN TERIMA KASIH}

Dengan selesainya penelitian ini, peneliti menyampaikan apresiasi yang sebesar-besarnya kepada pihakpihak yang telah terlibat dalam terlaksananya penelitian ini, terutama kepada mahasiswa PGSD UM.Buton yang berkenan menjadi sampel penelitian dan rekan-rekan Dosen PGSD UM.Buton. 
226 Kondisi Psikologis Mahasisawa PGSD Universitas Muhammadiyah Buton (UMB) dalam Pelaksanaan Pembelajaran Daring di Masa Pandemi - Syamsurijal, Sarwan

DOI: https://doi.org/10.31004/edukatif.v3i1.290

\section{DAFTAR RUJUKAN}

Deliviana, E., Erni, M. H., Hilery, P. M., Naomi, N. M., \& Indonesia, U. K. (n.d.). PENGELOLAAN KESEHATAN MENTAL MAHASISWA BAGI OPTIMALISASI PEMBELAJARAN ONLINE DI MASA PANDEMI COVID-19. 129-138.

Dewi, W. A. F. (2020). Dampak Covid-19 Terhadap Implementasi Pembelajaran Daring Di Sekolah Dasar [The Impact of Covid-19 on the Implementation of Online Learning in Primary Schools]. Edukatif: Jurnal Ilmu Pendidikan.

Fuadi, T. M., \& Irdalisa. (2020). Covid 19: Antara Angka Kematian dan Angka Kelahiran. Jurnal Sosiologi Agama Indonesia (JSAI). https://doi.org/10.22373/jsai.v1i3.767

Hartono \& Boy S. (2012). Psikologi Konseling. In Konseling.

Kartika, D. (2020). Faktor - Faktor Kecemasan Akademik Selama Pembelajaran Daring Pada Siswa SMA di Kabupaten Sarolangun. 4, 3544-3549.

Kartika, R. (2020). ANALISIS FAKTOR MUNCULNYA GEJALA STRES PADA MAHASISWA AKIBAT PEMBELAJARAN JARAK JAUH DI MASA PANDEMI COVID-19. Edukasi Dan Teknologi.

Marzuki. (2012). Politik Pendidikan Nasional dalam Bingkai Undang-undang Sistem Pendidikan Nasional. Jurnal Penelitian Humaniora, 17(2), 16-38.

Mubarok, A., Aprilia, N. T., \& Susanti, S. (2020). ANALISIS KEPUASAN PENGGUNA LAYANAN GOOGLE-FORMS SEBAGAI MEDIA SURVEY ONLINE MENGGUNAKAN DELONE \& MCLEAN. Jurnal Informatika. https://doi.org/10.31294/ji.v7i2.7967

Pratama, Y. (2013). Pemanfaatan Ekstrak Daun Jati (Tectona grandis linn. f.) Sebagai Indikator Titrasi AsamBasa. In Skripsi Universitas Negeri Semarang.

Rohman, A. (2019). DAMPAK PSIKOLOGI BELAJAR DALAM PEMBELAJARAN AKTIF BAGI PESERTA DIDIK MADRASAH IBTIDAIYAH. MAGISTRA: Media Pengembangan Ilmu Pendidikan Dasar Dan Keislaman. https://doi.org/10.31942/mgs.v10i1.2715

Rosali, E. S. (2020). Aktifitas Pembelajaran Daring Pada Masa Pandemi Covid -19 Di. Geography Science Education Journal (GEOSEE).

Rozaq, A., \& Sofyana, L. (2019). Penalaran Berbasis Kasus Untuk Menentukan Pajak Bumi Dan Bangunan. Jurasik (Jurnal Riset Sistem Informasi Dan Teknik Informatika).

https://doi.org/10.30645/jurasik.v4i1.112

Sofyana, L., \& Rozaq, A. (2019). PEMBELAJARAN DARING KOMBINASI BERBASIS WHATSAPP PADA KELAS KARYAWAN PRODI TEKNIK INFORMATIKA UNIVERSITAS PGRI MADIUN. Jurnal Nasional Pendidikan Teknik Informatika (JANAPATI). https://doi.org/10.23887/janapati.v8i1.17204

Suntiawati, P., \& Westa, W. (2015). PREVALENSI TINGKAT KECEMASAN REMAJA DI PANTI ASUHAN WISMA ANAK-ANAK HARAPAN DALUNG BALI TAHUN 2015. Intisari Sains Medis. https://doi.org/10.15562/ism.v3i1.72

Syah, M. (2010). Psikologi Pendidikan dengan pendekatan Baru. In Psikologi Pendidikan dengan pendekatan Baru. 